\title{
ANALISIS NILAI - NILAI PENDIDIKAN KARAKTER DALAM FILM UPIN DAN IPIN PRODUKSI LES COPAQUE TAHUN 2010
}

\author{
Fazrul Sandi Purnomo \\ fazrulsandi.fs@gmail.com \\ Universitas Muhammadiyah Bangka Belitung
}

\begin{abstract}
Abstrak
The purpose of this study to determine the values of character education in the film of Upin and Ipin production Les' Copaque in 2010. This research uses descriptive method. The data in this research is the dialogue in the film of Upin and Ipin production in 2010 that contains the value of character education. Based on the analysis found values contained in the film of Upin and Ipin production Les' Copaque in 2010 is religious, honest, tolerance, discipline, hard work, creative, curiosity, appreciate the achievements, friendly, social care / care about others, responsibility, brave, cooperation, mutual help, wisdom, respect for all life forms and environment that care of each other, respect for others / public politeness, and self-respect. There is value that specially treated is patriotism because it involves nationalism. Upin and Ipin Film production of Les Copaque in 2010 containing values of character education.
\end{abstract}

Kata Kunci: The values, education character, Film.

\section{PENDAHULUAN}

Pendidikan merupakan investasi terbaik bagi suatu bangsa, apalagi untuk bangsa yang sedang berkembang dan sedang giat membangun. Pembangunan bangsa hanya bisa dilakukan oleh manusia yang telah dipersiapkan melalui pendidikan. Dengan demikian, pendidikan dilakukan untuk menentukan kelangsungan hidup bangsa dan negara.

Pendidikan yang baik adalah pendidikan yang dapat mempersiapkan anak didik agar mampu mengakses peran mereka di masa yang akan datang. Artinya, pendidikan hendaknya dapat membekali siswa dengan berbagai macam keterampilan yang dibutuhkan sesuai dengan keadaan zaman, sehingga mereka dapat menjalankan dan memenuhi tujuan hidup secara efektif dan efisien.
Pendidikan membantu manusia dalam menumbuhkembangkan potensipotensi kemanusiaan yang ada dalam dirinya. Potensi kemanusiaan merupakan benih untuk mengembangkan seseorang menjadi manusia seutuhnya. Untuk menjadi manusia seutuhnya, nilai-nilai luhur ditananamkan melalui pendidikan. Nilai-nilai yang ditanam itu nantinya akan membentuk karakter pada diri manusia. Karakter pada diri manusia inilah yang akan menentukan suatu bangsa itu adalah bangsa yang maju atau bangsa yang mundur.

Karakter merupakan cara berpikir dari individu yang menjadi ciri khas dan digunakan dalam kehidupan di masyarakat serta mendorong bagaimana seseorang itu untuk bertindak dalam segala hal. Jadi, bila individu memiliki karakter yang baik maka kehidupan di masyarakat akan baik dan sebaliknya bila 
individu memiliki karakter yang buruk maka kehidupannya di masyarakat akan buruk pula.

Karakter mulia berarti individu memiliki pengetahuan tentang potensi dirinya yang ditandai dengan nilai-nilai yang mulia. Individu yang berkarakter baik atau unggul adalah seseorang yang berusaha melakukan hal-hal yang baik terhadap Tuhan YME, dirinya, sesama, lingkungan, bangsa dan negara serta dunia internasional pada umumnya dengan mengoptimalkan potensi (pengetahuan) dirinya dan disertai dengan kesadaran, emosi, dan motivasi (perasaannya). Pendidikan karakter perlu dilakukan untuk membangun karakter seseorang.

Tidak ada yang menyangkal bahwa karakter merupakan aspek yang penting untuk kesuksesan manusia di masa depan. Karakter yang kuat akan membentuk mental yang kuat. Sedangkan mental yang kuat akan melahirkan spirit yang kuat, pantang menyerah, berani mengarungi proses panjang, serta menerjang arus badai yang bergelombang dan berbahaya. Menurut Raka dkk.(dalam Asmani 2011: 20) faktor karakter mempunyai kontribusi yang paling besar terhadap persepsi berhasil atau tidaknya seseorang dalam kehidupan.

Pendidikan karakter merupakan pendidikan yang mengembangkan nilainilai budaya dan karakter bangsa, sehingga mereka memiliki dan menerapkan nilai-nilai tersebut dalam kehidupan dirinya sebagai anggota masyarakat dan warga negara yang relegius, produktif, dan kreatif (Sulistyowati, 2012: 22). Betapa pentingnya pendidikan karakter bagi seseorang. Melalui pendidikan karakter inilah, seseorang mampu memiliki sikap yang bertanggung jawab sebagai penerus bangsa sehingga kondisi bangsa dan negara bisa jauh lebih baik. Dengan karakter itu pula ketentraman dalam bermasyarakat dapat terwujud dan terjaga dengan baik.

Pendidikan karakter sebenarnya bukan hal yang baru. Sejak awal kemerdekaan, masa orde lama, masa orde baru, dan masa reformasi sudah dilakukan dengan nama dan bentuk yang berbeda-beda.

Seperti Dalam undang-undang nomor 20 tahun 2003 tentang Sistem Pendidikan Nasional telah ditegaskan bahwa Pendidikan Nasional berfungsi mengembangkan kemampuan dan membentuk watak serta peradaban bangsa yang bermartabat dalam rangka mencerdaskan kehidupan bangsa, bertujuan untuk berkembangnya potensi peserta didik agar menjadi manusia yang beriman dan bertakwa kepada Tuhan Yang Maha Esa, berakhlak mulia, sehat, berilmu, cakap, kreatif, mandiri, dan menjadi warga yang demokratis serta bertanggung jawab.

Pendidikan karakter dapat diperoleh melalui tontonan terlebih lagi untuk anak-anak. Anak-anak mudah terpengaruh oleh perilaku yang ditunjukkan oleh tokoh di dalam film. Salah satu tontonan yang disukai oleh anak-anak adalah film Upin dan Ipin.

Film Upin dan Ipin adalah film yang diproduksi Les Copaque dari negara Malaysia yang kemudian film ini ditayangkan di Indonesia. Dengan begitu, akan dilihat pula kecocokan nilai berdasarkan norma dan nilai yang dimiliki di Negara Indonesia.

Upin dan Ipin bukan sekedar tontonan yang fungsinya menghibur 
semata tetapi ada unsur pendidikan di dalamnya. Unsur pendidikan di dalam film ini dapat membentuk karakter dari anak-anak yang menontonnya. Karena secara umum, anak-anak menyukai film kartun dan tak jarang juga menirukan perilaku yang terdapat di film tersebut. Untuk itu perlu kita ketahui nilai pendidikan karakter dalam film Upin dan Ipin ini.

Dari nilai - nilai pendidikan karakter tersebut, terdapat nilai yang bisa berlaku secara universal, artinya nilai tersebut bisa dipakai atau cocok dimana saja walaupun berasal dari negara yang berbeda. Namun, terdapat juga nilai yang tidak bisa berlaku secara universal karena menyangkut nasionalisme.

Peneliti ingin melihat lebih banyak lagi nilai-nilai karakter yang terdapat di dalam film Upin dan Ipin ini. Peneliti berharap nantinya nilai-nilai yang telah ditemukan oleh peneliti dapat dijadikan bantuan untuk membentuk karakter anak baik itu dalam pendidikan formal, informal maupun nonformal.

Berdasarkan hal itu maka penulis ingin menemukan nilai pendidikan karakter yang ada di dalam film Upin dan Ipin melalui penelitian ini, sehingga penelitian ini diberi judul "Analisis Nilai Nilai Pendidikan Karakter dalam Film Upin dan Ipin Produksi Les Copaque Tahun 2010". Tujuan dari penelitian ini adalah untuk mengetahui nilai-nilai pendidikan karakter dalam film Upin dan Ipin produksi Les' Copaque tahun 2010.

\section{METODE PENELITIAN}

Metode dalam penelitian ini adalah deskriptif. Metode deskriptif adalah salah satu metode penelitian yang banyak digunakan pada penelitian yang bertujuan untuk menjelaskan suatu kejadian. Seperti yang dikemukakan oleh Sugiyono (2013:35) metode penelitian deskriptif adalah metode penelitian yang dilakukan untuk mengetahui nilai variabel mandiri atau lebih (independen) tanpa membuat perbandingan atau menggabungkan antara variabel satu dengan yang lain. Penelitian ini dilakukan di Bengkulu pada bulan Maret dan April 2016. Data penelitian ini adalah dialog pada film Upin dan Ipin produksi tahun 2010 yang mengandung nilai pendidikan karakter. Sumber data penelitian adalah film Upin dan Ipin produksi Let's Copaque tahun 2010 yang terdiri dari 5 judul cerita yaitu (1) Air Kolah Air Laut, (2) Basikal Baru (3) Berkebun, (4) Kisah Dua Malam, dan (5) Gosok Jangan Tak Gosok. Teknik pengumpulan data merupakan langkah yang paling strategis dalam penelitian, karena tujuan utama dari penelitian adalah mendapatkan data. Tanpa mengetahui teknik pengumpulan data, maka peneliti tidak akan mendapatkan data yang diharapkan (Sugiyono, 2013: 224). Teknik pengumpulan data dalam penelitian ini menggunakan teknik Observasi.

Nasution (dalam Sugiyono, 2013: 226) menyatakan bahwa observasi adalah dasar semua ilmu pengetahuan. Para ilmuwan hanya dapat bekerja berdasarkan data, yaitu fakta mengenai dunia kenyataan yang diperoleh melalui observasi. Sedangkan Marshall (dalam Sugiyono, 2013: 226) menyatakan bahwa melalui observasi, peneliti belajar tentang perilaku, dan makna dari perilaku tersebut.

Obyek penelitian dalam penelitian kualitatif yang diobservasi menurut Spradley (dalam Sugiyono, 2013: 229) dinamakan situasi sosial, yang 
terdiri atas tiga komponen, yaitu place (tempat), actor (pelaku), activities (aktivitas).

Jadi, peneliti belajar tentang perilaku dan maknanya yang terdapat di dalam situasi sosial melalui observasi. Dalam hal ini yang di observasi adalah fakta situasi sosial yang terdapat di dalam film Upin dan Ipin Volume 1 dan 2. Instrumen dalam suatu penelitian adalah alat yang digunakan untuk mengumpulkan data. Dalam penelitian kualitatif, yang menjadi instrumen atau alat penelitian adalah peneliti itu sendiri. Peneliti kualitatif sebagai human instrument, berfungsi menetapkan fokus penelitian, memilih sumber data, melakukan pengumpulan data, analisis data, menafsirkan data dan membuat kesimpulan atas temuannya. Alat bantu yang digunakan adalah perlengkapan alat tulis dan seperangkat komputer untuk memutar film dan membuat transkrip data penelitian.

\section{HASIL DAN PEMBAHASAN}

Secara umum pokok permasalahan yang akan dibahas dalam hasil penelitian ini adalah nilai - nilai yang terkandung dalam film Upin dan Ipin produksi Les' Copaque tahun 2010. Dalam pembahasan ini akan dibahas nilai-nilai pendidikan karakter dengan merujuk pada teori yang ada sesuai dengan masalah yang diteliti. Nilai pendidikan karakter yang ditemukan dalam penelitian ini dilihat berdasarkan nilai pendidikan karakter menurut pendapat Lickona dan berdasarkan rumusan nilai pendidikan karakter dari Kemendiknas.

Lickona (2013: 70) mengatakan bahwa hormat dan tanggung jawab merupakan yang menjadi dasar landasan yang tidak hanya memperbolehkan, tetapi mengharuskan untuk memberikan pendidikan. Nilai - nilai pendidikan karakter berdasarkan pendapat Lickona tersebut dapat dirumuskan, yaitu penghormatan terhadap diri sendiri, penghormatan terhadap orang lain / kesopanan umum, penghormatan terhadap semua bentuk kehidupan dan lingkungan yang saling menjaga satu sama lain, hormat terhadap sesuatu yang dimiliki, rasa hormat terhadap sesuatu kewenangan, keadilan, kejujuran, sikap adil, toleransi, kebijaksanaan, disiplin diri, tolong menolong, peduli sesama, kerja sama, berani, dan demokrasi.

Selain pendapat Lickona, untuk memperdalam nilai-nilai yang dibutuhkan dalam pendidikan karakter maka ditambah dengan 18 nilai pendidikan karakter berdasar Kemdikbud (2011: 8), yaitu Religius, Jujur, Toleransi, Disiplin, Kerja keras, Kreatif, Mandiri, Demokratis, Rasa Ingin Tahu, Semangat Kebangsaan, Cinta Tanah Air, Menghargai Prestasi, Bersahabat/ Komunikatif, Cinta Damai, Gemar Membaca, Peduli Lingkungan, Peduli Sosial, dan Tanggung Jawab.

$$
\text { Berdasarkan nilai - nilai }
$$

pendidikan karakter yang dirumuskan oleh Lickona dan Kemdikbud di atas, tidak semua nilai - nilai itu terkandung dalam film Upin dan Ipin produksi Les Copaque tahun 2010 ini. Nilai - nilai pendidikan karakter yang terkandung dalam film animasi Upin dan Ipin yaitu religius, jujur, toleransi, disiplin, kerja keras, kreatif, Rasa ingin tahu, menghargai prestasi, bersahabat, Peduli sosial/peduli sesama, tanggung jawab, berani, kerja sama, tolong menolong, kebijaksanaan, penghormatan terhadap semua bentuk kehidupan dan lingkungan 
yang saling menjaga satu sama lain, penghormatan terhadap orang lain / kesopanan umum, dan penghormatan terhadap diri sendiri. Sedangkan nilai yang tidak terkandung adalah mandiri, demokratis, semangat kebangsaan, cinta tanah air, cinta damai, gemar membaca, peduli lingkungan, rasa hormat terhadap suatu kewenangan, hormat terhadap sesuatu yang dimiliki, dan adil.

Setiap episode memiliki nilai karakter yang dominan. Dalam episode Air Kolah Air Laut, nilai yang dominan adalah nilai religius, kreatif, berani, bijaksana, dan Penghormatan terhadap semua bentuk kehidupan dan lingkungan yang saling menjaga satu sama lain.

Kemudian pada episode yang kedua dengan judul Basikal Baru, nilai dominan yang terlihat adalah nilai peduli sosial. Nilai peduli sosial adalah sikap dan tindakan yang selalu ingin memberi bantuan pada orang lain dan masyarakat yang membutuhkan.

Selanjutnya episode ketiga pada film Upin dan Ipin. Judul dalam episode ini adalah Berkebun. Nilai dominan yang terdapat dalam episode ini adalah nilai menghargai prestasi. Menghargai prestasi adalah sikap dan tindakan yang mendorong dirinya untuk menghasilkan sesuatu yang berguna bagi masyarakat, dan mengakui, serta menghormati keberhasilan orang lain.

Judul berikutnya dalam film Upin dan Ipin ini adalah Kisah Dua Malam. Dalam episode ini nilai yang dominan adalah nilai religius. Nilai religius adalah sikap dan perilaku yang patuh dalam melaksanakan ajaran agama yang dianutnya, toleran terhadap pelaksanaan ibadah agama lain, dan hidup rukun dengan pemeluk agama lain. Dengan begitu, episode ini akan lebih menekankan pada nilai religius untuk ditanamkan pada anak.

Selanjutnya film Upin dan Ipin yang dilihat nilai karakternya adalah episode yang berjudul Gosok Jangan Tank Gosok. Dalam episode ini, nilai yang dominan adalah nilai peduli sosial.

Dari semua nilai pendidikan karakter yang dominan di antara kelima judul tersebut terdapat nilai yang paling dominan. Nilai yang paling dominan di antara kelima judul tersebut ketika meneliti film animasi Upin dan Ipin produksi Les Copaque tahun 2010 adalah nilai peduli sosial/peduli sesama. Peduli sosial/peduli sesama adalah sikap dan tindakan yang selalu ingin memberi bantuan pada orang lain dan masyarakat yang membutuhkan.

Dalam dialog A.2.114 terlihat Memei yang peduli kepada Fizi. Melihat Fizi yang tidak diberikan tumpangan oleh Ihsan, Memei bersedia meminjamkan sepedanya kepada Fizi.

Nilai - nilai dalam pendidikan karakter memiliki sifat yang universal. Jadi kemana pun dan dimana pun nilai nilai pendidikan karakter selalu ada. Namun memang ada nilai yang harus diberikan perhatian khusus yaitu nilai nilai yang mengandung sikap nasionalisme.

Berdasarkan sikap nasionalisme, terdapat nilai pendidikan karakter yang harus mendapatkan perhatian khusus. Perhatian khusus ini diberikan agar nilai pendidikan karakter tersebut tidak merusak dan merubah sikap nasionalisme pada diri anak. Nilai yang harus mendapatkan perhatian khusus adalah cinta tanah air dan semangat kebangsaan. Namun, yang terkandung dalam 5 episode ini adalah nilai cinta tanah air yang dilihat dari penggunaan 
bahasa tokoh - tokoh yang ada di dalamnya. Berdasarkan hal itu, tindak lanjut yang dilakukan adalah pemberian label Bimbingan Orang Tua (BO) pada film animasi yang berasal dari negara lain.

\section{SIMPULAN}

Berdasarkan hasil penelitian dan pembahasan yang telah dilakukan, maka dapat diambil kesimpulan bahwa film animasi Upin dan Ipin produksi Les Copaque dalam penelitian ini mengandung nilai - nilai pendidikan karakter yaitu (1) religius, contohnya ketika Opah memberikan nasihat kepada Upin dan Ipin agar tidak mengeluh karena sesungguhnya hujan itu adalah Rahmat dari Tuhan YME. (2) jujur, contohnya saat jarjit menepati janjinya bila Ipin bisa menjawab pantunnya maka Memei diperbolehkan melangkah satu langkah ke arah kapal. (3) toleransi, contohnya ketika Jarjit menerima pantun yang diucapkan oleh Ipin walaupun ada sedikit kesalahan dari pantunnya, (4) disiplin, contohnya setelah bermain Upin dan Ipin pulang ke rumah tepat waktu, (5) kerja keras, contohnya Mail mampu mengendarai sepeda untuk orang dewasa dikarenakan berlatih dengan keras walaupun harus terjatuh dan mengalami luka disekujur tubuhnya, (6) kreatif, contohnya ketika Dokter Rafi memberikan sikat gigi gratis agar anak anak mau belajar cara menggosok gigi dengan benar, (7) rasa ingin tahu, contohnya ketika Ipin belum mengerti yang dimaksud dengan rahmat dan menanyakannya kepada Opah, (8) menghargai prestasi, contohnya ketika Dokter Rafi memberikan pujian kepada Ihsan yang telah rajin menyikat gigi, (9) bersahabat, contohnya ketika Dzul sangat antusias mendengar dan merespon pembicaraan Upin, (10) peduli sosial/peduli sesama, contohnya ketika Upin dan kawan - kawan menjenguk Mail yang tidak masuk sekolah, (11) tanggung jawab, contohnya ketika Upin dan Ipin di ajak bermain oleh Mail, akan tetapi Upin menolak karena harus menyelesaikan tugasnya untuk menanam sayur, (12) berani, contohnya ketika siswa TK Tadika Mesra merasa takut saat diadakan pemeriksaan gigi dengan bersembunyi di bawah meja, Memei tetap tenang dan menghadapi pemeriksaan gigi seperti biasa, (13) kerja sama, contohnya ketika Mail bekerja sama dengan Upin dan Ipin untuk mendahului Ihsan dalam balapan. Mail bertugas mengendarai pesawat sedangkan Upin dan Ipin bertugas mengurus mesin pesawat dalam hal penambah kecepatan dan pertahanan, (14) tolong menolong, contohnya ketika Memei menolong Upin dan Ipin menanam sayur karena mereka tidak mengetahui bagaimana cara menanam sayur, (15) kebijaksanaan, contohnya ketika Opah memberitahukan kepada Upin dan Ipin manfaat hujan bagi lingkungan dan air sangat diperlukan bagi kehidupan di bumi, (16) penghormatan terhadap semua bentuk kehidupan dan lingkungan yang saling menjaga satu sama lain, contohnya ketika Opah menasihati Upin dan Ipin agar tidak terjadi banjir, (17) penghormatan terhadap orang lain / kesopanan umum, contohnya ketika Memei menyapa Opah dan Kak Ros saat berkunjung untuk mengajak Upin dan Ipin bermain, (18) penghormatan terhadap diri sendiri, contohnya ketika Memei mengendarai sepeda dengan menggunakan helm sepeda untuk 
pengamanan diri, dan (19) Cinta tanah air, contohnya ketika Upin, Ipin dan kawan - kawan menggunakan bahasa negara mereka.

Berdasarkan penelitian ini, tidak semua nilai - nilai karakter terkandung dalam setiap episode. Akan tetapi nilai nilai yang ada telah bisa menanamkan karakter pada anak. Sehingga bagi anak yang menonton film Upin dan Ipin ini, nilai pendidikan karakter bisa tertanam pada dirinya. Dari contoh di atas bahwa film Upin dan Ipin berniat tidak hanya memberikan hiburan saja akan tetapi juga memberikan nilai-nilai karakter yang terkandung didalamnya.

\section{Daftar Pustaka}

Abidin, Yunus.2012.Pembelajaran Bahasa Berbasis Pendidikan Karakter.Bandung: Refika Aditama.

Aqib, Zainal dan Sujak.2011.Panduan dan Aplikasi Pendidikan Karakter. Bandung: Yrama Widya.

Aqib, Zainal.2011.Pendidikan Karakter Membangun Perilaku Positif Anak Bangsa.Bandung: Yrama Widya.

Arsyad, Azhar. 2011. Media Pembelajaran. Jakarta: PT Raja Grafindo Persada.

Asmani, Jamal Ma'mur.2011.Buku Panduan Internalisasi Pendidikan Karakter di Sekolah.Yogyakarta: Diva Press.

Danesi, Marcel. 2010. Pengantar Memahami semiotika Media. Yogyakarta: Jalasutra.
Emzir.2011.Metode Penelitian Kualitatif: Analisis Data.Jakarta: PT RajaGrafindo Persada.

Javandalasta, P. 2011. 5 Hari Mahir Bikin Film. Surabaya: Java Pustaka Group.

Kemdiknas.2011. Panduan Pelaksanaan Pendidikan Karakter. Jakarta: Puskur-Balitbang, Kemdiknas.

Kesuma, Dharma dkk.2012.Pendidikan Karakter Kajian Teori dan Praktik di Sekolah. Bandung: PT Remaja Rosdakarya Offset.

Khan, Yahya.2010.Pendidikan Karakter Berbasis Potensi Diri.Yogyakarta: Pelangi Publishing.

Lickona. Thomas. 2013. Mendidik untuk Membentuk Karakter: Bagaimana Sekolah dapat Memberikan Pendidikan Tentang Sikap Hormat dan Tanggung Jawab. Jakarta: PT Bumi Aksara.

Mu'in, Fatchul.2011. Pendidikan Karakter Konstruksi Teoretik dan Praktik.Jogjakarta : Ar-Ruzz Media.

Muslich, Masnur.2011.Pendidikan Karakter: Menjawab Tantangan Krisis Multidimensional.Jakarta: Bumi Aksara.

Nurgiyantoro, Burhan. 2010. Teori Pengkajian Fiksi. Yogyakarta: Gajah Mada University Press.

Pratista, Himawan. 2008. Memahami Film. Yogyakarta: Homerian Pustaka. 
Rabiger, Michael. 2009. Directing the Documentary. Oxford: Elsevier.

Sadiman, Arif S. 2003. Media Pendidikan: Pengertian, Pengembangan dan Pemanfaatannya. Jakarta: PT Raja Grafindo Persada.

Sugiyono.2013.Metode Penelitian Kuantitatif, Kualitatif, dan $R \& D$.Bandung: Alfabeta.

Sukmadinata, Nana Syaodih. 2005. Metode Penelitian Pendidikan. Bandung: Rosda.
Suyadi.2013.Strategi Pembelajaran Pendidikan Karakter.Bandung: PT Remaja Rosdakarya Offset.

Usman, M. Basyiruddin dan Asnawir. 2002. Media Pembelajaran. Jakarta: Delia Citra Utama.

Wibowo, Agus.2013.Pendidikan Karakter di Perguruan Tinggi.Yogyakarta: Pustaka Pelajar.

Wiyani, Novan Ardy.2013.Membumikan Pendidikan Karakter di SD.Yogyakarta: Ar-ruzz Media. 